TURIZAM

Volume 14 , Issue 2

78-86 (2010)

\title{
Architecture as a Tool for Branding in Rural Istrian Tourism Destination
}

\author{
Ivana Medica* \\ Pavlo Ružić ** \\ Tomislav Ružićc*** \\ Received: April 2010 | Accepted: June 2010
}

\begin{abstract}
Natural and protected environments with authentic widespread traditional construction have become one of the fundamental touristic resources. Traditional architecture is a very crucial part of collective cultural heritage. Although it is ample and widespread, only since recent times it has been given its economical value as well as it has been included in tourism. According to the context above, authors have come up with a hypothesis stating that with implying branding of traditional architectural heritage, a positive influence on enrichment of touristic offerings of certain destination will be achieved. The authors defend and fulfill their hypothesis by analyzing different research on the example of rural destinations in Istria.
\end{abstract}

Key words: branding, architecture, touristic resources, touristic offerings, rural tourism destination of Istria.

\section{Introduction}

The environment is a major provider of a tourism offering. However, without a superstructure, the environment is not capable of fulfilling all the spatial functions of tourism. It provides insight into the human environment with objects, plants, atmosphere, and while enabling life, it impacts on the development of living beings. Therefore, by encroaching on space, architecture and designers have the ability of either improving or destroying it, thus depriving space, as a primary provider of the tourism offering, of its original value.

The works of many authors speak of the role of architecture in designing space, the environment and spatial appeal, in safeguarding space from devastation, etc. To prevent spatial devastation, a scientific framework for managing urban and natural space has been estab-

\footnotetext{
* Teacher Training Faculty, Zagreb, medicaivana@gmail.com

** Institute of Agriculture and Tourism, Poreč, pavlo@iptpo.hr

*** Polytechnic of Pula, tope@net.hr
} 
lished (Mazzoti, Morgenstern, I997, I7I-I8I). The paper, "Attributes of Modern Landscape Architecture and Education" (Gazvoda, 20O2, II7-I33), looks at the role of architecture in designing landscapes relative to the needs of tourists for nature. Some papers examine the ecological functions and structural element of landscape visualisation (Hehl-Lange, 2OOI, IO7-II5), while others provide examples for the development of regions based on the ecological principles for urban areas. (Freeman, Buck, 2003, I6I-I73)

Based on the special features, objectives and forms of tourism marketing, architecture can contribute substantially to shaping the traditional architectural heritage and the tourism offering. Increasingly in recent times, traditional architecture is viewed as a vital part of cultural heritage that, being so abundant and widespread, needs to be commercially valorised and become a part of reconstruction and change-of-use programs to meet the requirements of modern life. Valorising traditional architectural heritage for tourism purposes is one of the many ways in which it can be preserved. In Istria, the rental price of reconstructed stone houses - in which natural building materials, such as stone and wood, and other elements of traditional architecture have been preserved - is very high. The daily rental fee for these types of houses ranges from EUR 500 - I.OOO and cannot be matched by almost any holiday-flat located on the coast (Ružić, Amidžić, Poropat, 2007, I6-I72). Not only do stone houses have higher daily rental fees, but they also have a longer occupancy rate measured in days than accommodation facilities in coastal areas.

\section{Data and Methodology}

In this paper, research is based on primary and secondary sources, and on proven scientific methods of domestic and foreign authors. Notable among the methods used are (Gazvoda, 2OO2, II7-I33): the landscape architecture method, and the method of creative landscape drawing, both uses to make e research on the typical landscape of the Istrian hinterland. Also used were methods, such as the spatial study method, (Larsen, Sharon, 2006, 85- IOO) and the method of four types of environment, both applied to explore the environment of rural Istria, particularly as concerns family house renovation, maintaining of the surrounding court-yards, housing and suburbs.

The spatial range of rural Istria has been defined by selecting districts and cities of the Istrian hinterland. If such districts and cities are partly situated on the coastland, then it will be forbidden to build a larger suburb in this area. The housing project of the rural Istria encompassing 27 districts and cities has been defined in this way.

The empiric part of the research has been based on the polling results conducted in 2007. The research tool used was the polling questionnaire containing several groups of questions, such as: questions regarding tourist habits of potential visitors, those aimed at researching distinctive features of tourists appertaining to a potential group of consumers that prefer rural to coastal tourism, as well as the ones intended to investigate preferences of the traditional architectural solutions as concerns accommodation capacities; namely the renovated Istrian stone villas, rural areas and landscape of the rural Istria. The questionnaires were tested before use in order to eliminate possible errors. The polling has been effected on the population specimen of the coastal and rural Istria. The distribution of questionnaires was carried out by personal distribution on the part of the IPTPO researchers. A suitable exemplar of over I,3OO questionnaires has been used in the polling. 


\section{Results and Discussion}

In keeping with the umbrella-branding concept, a survey was conducted in Istria's rural regions in 2007. The purpose of the survey was to explore the level of tourist satisfaction with rural environment and authenticity. Consistent with this, the authors again underscore the vital role of architecture in achieving harmony with nature, residents, history and tourists. The research was broadened with questions to tourists regarding the possibility of buying real estate in rural areas and their willingness to adapt the architecture of this real estate to the authentic style of Istrian rural architecture. Results are summarised in Graphs I and 2.

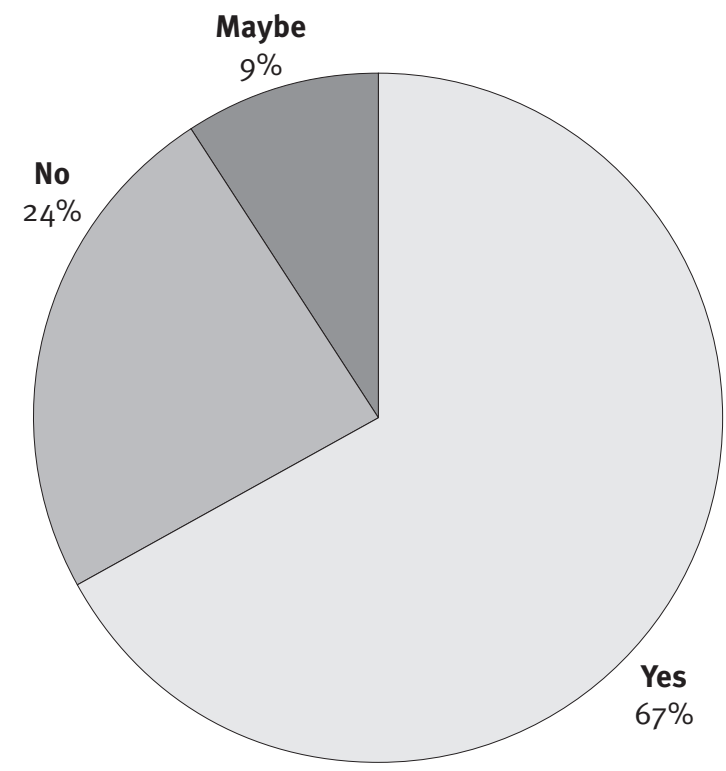

Graph 1 Attitudes of tourists in rural Istria regarding the purchase of real-estate Source: Research Institute of Agriculture and Tourism Poreč, 2007.

According to the results presented in (Graph I), 67 percent of the tourists surveyed in the rural region of Istria would be willing to buy real-estate in this area. This confirms the hypothesis of the expansion of the real-estate market and the disproportionate relationship of supply and demand. Furthermore, 9 percent of the respondents stated they might be willing to buy real-estate for holiday purposes, while 24 percent stated they would not be willing to do so.

An urban style should not be applied to Mediterranean and mountain areas, because it fails to provide tourists coming from urban centres with the new and improved values that are characteristic of these destinations. $67 \%$ of tourists would respect traditional style of rural area during decoration of their houses and that is very positive for further control of architecture development.

Important advancements in protecting architectural heritage began to take place at the turn of the last century when it became clear that rural heritage is a potential tourism attraction that can help in developing specific forms of the tourism offerings. The Istrian County was the first in Croatia to begin to valorise its rural areas for tourism purposes, in particular, its traditional stone architecture. In the past I5 years, more than 200 stone houses have 


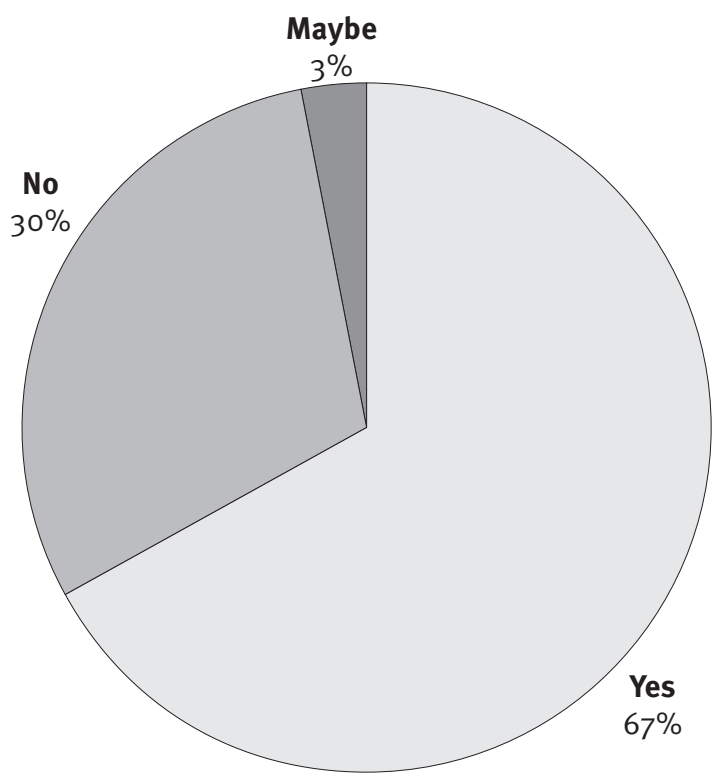

Graph 2 Attitudes of tourists in rural Istria on purchasing and renovating real-estate according to traditional architecture

Source: Institute of Agriculture and Tourism, Poreč, authors’ research 2007.

been reconstructed or built in the Istrian County. Constructed and furnished in accordance to traditional architecture, these stone houses represent a highly competitive product on the tourism market. The experiences of and data available from tourist agencies engaged in providing accommodations in Istrian stone houses confirm this fact.

Table I presents data on available capacities, daily rental prices and average occupancy rates for villas and holiday-flats in stone houses designed in accordance with the requirements of traditional architecture in rural Istria. The data has been obtained from agencies specialised in selling tourism accommodation in rural Istria. "Istrian Experience" is an agency that owns 33 luxurious stone houses built to the standards of Istria's traditional architecture. In addition to providing accommodation, these villas are equipped with libraries, wine cellars, swimming pools, etc. and reach a price ranging from EUR 500 - I.OOO per day.

The agency "Riva Tours" rents out IOO houses in the Istrian hinterland. Out of these houses, ten are luxurious and can achieve a price ranging from EUR 300 - 600 per day with the average occupancy rate of IOO - 220 days a year. On the other hand, the agency also offers holiday-flats and houses that are furnished in a more mediocre way, and these achieve a daily rental price of EUR 50 - 200 and an average annual occupancy rate of 30 - IOO days. A comparison of these performance indicators clearly shows that stone hous-

Table 1. Capacities, occupancy rates and rental prices of Istrian stone houses

\begin{tabular}{|l|c|c|c|}
\hline Name of Agency & $\begin{array}{c}\text { Number of available } \\
\text { stone houses }\end{array}$ & $\begin{array}{c}\text { Rental price per house } \\
\text { per day in EUR }\end{array}$ & $\begin{array}{c}\text { Average annual } \\
\text { occupancy rate in days }\end{array}$ \\
\hline Istrian Experience & 33 & $500-1000$ & - \\
\hline Riva Tours & 10 & $300-600$ & $100-220$ \\
\hline Riva Tours & 90 & $50-200$ & $30-100$ \\
\hline
\end{tabular}

Source: Catalogue, Riva Tours, 2007.; www.istrian-experience.com 
es designed according to traditional architecture and located in a preserved natural environment achieve top-level results.

This section of the paper brings the results of previous research, as well as results obtained from the original research of the authors. In collaboration with a team of experienced architects and based on research conducted, facts have been established that underscore the importance of architecture in preserving the environment and the authenticity of places that are becoming "holiday oases" for many tourists. The results obtained from the authors' own research are based on the attitudes of tourists, local authorities and architects.

Based on the special features, objectives and forms of tourism, architecture can contribute substantially in shaping the tourism offering. "Architecture is the activity and skill of designing and aesthetically shaping buildings" (Anić, 1998, 29). Furthermore, "architecture in its broadest sense is the skill of building organised spaces for human dwelling, but also for various other purposes and needs. The basic elements of architecture are interior space, that serves a specific use - for living, working, religion, leisure - and an external body (mantle), the constructive component which creates and protects the interior space, while its compositional and form-related elements align the various parts of a building (walls, ceilings, apertures, columns, decorative details) and bring them together in a harmonious whole" (General Encyclopaedia, 1977, 242-246). "Architecture is shaped by the spirit of the times, and this spirit is shaped by the depths of the past, the knowledge of the present, and the predictions of future" Cresti, I969, 5). In addition, "distinctions are made in architecture with regard to styles in construction" (Koch, I997), "the design of urban areas" (Halprin, I974), civil engineering (Marasović, I994), residential architecture (Strižić, 1997), and with regard to theoretical approaches (Conrads, I997, 25), construction typologies (De Chiara, Crosbie, I997, 25), champions of architecture from Le Corbusier to Van de Valde (Dobrović, I963, I7, 3I), movements in architecture (Jencks, I986), in creating architectural forms etc.

An artistic activity of human society, architecture is based on the development of technical and structural knowledge, and advancements in static's. Activities in architecture involve designing and executing logically and functionally organised, aesthetically balanced and conceptually defined construction of specific areas and towns.

The above is an indication of the broad range of opportunities that exist for using architecture in designing an offering and branding a tourism destination on the principles of sustainable development that help to achieve balanced economic growth, protect and preserve the environment, and respect and promote social and human rights.

Clearly, the architecture of any tourism facility can be defined as an ultimately designed intervention in solid construction in a given space. Its use is aimed at meeting the psychological aspects of holidaymaking (relaxation), sports and recreation, and it should blend in with the natural environment creating an aesthetic and functional ambience, instead of degrading it. Thus, architecture becomes the primary purpose of a facility, and this is especially felt in tourism. A region's environment conditions help determine the typology of rural architecture (www.heartofistria.org):

- the morphological features of a region

- the vicinity of water, influencing the development of settlements

- the properties of soil for farming

- infrastructure

- spiritual environment

- urbanisation

- ruralisation 


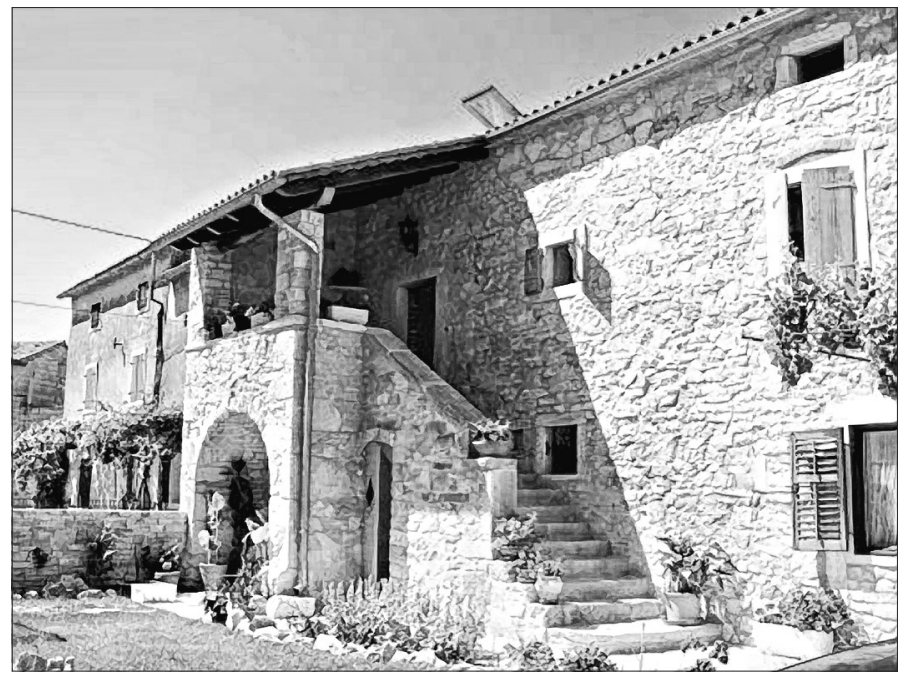

Figure 1 An authentic Istrian house

Source:www.heartofistria.org/fileadmin/documents/news/OrbanicArhitektura_ambijenta.pdf

Techniques used in rural Istrian architecture:

- patinating plaster using earthen pigments

- patinating wooden panelling

- timber waxing

- the use of old furniture

- the production of simple furniture and household equipment using second-hand materials.

The following figure illustrates all elements required in preserving and making indigenous Istrian rural architecture.

In recent years, rural Istria has undergone huge changes in terms of architecture. Due to the disproportionate relationship of supply and demand on the real-estate market of Istria, new trends have emerged in construction and architecture that increasingly diverge from what is considered "traditional and indigenous". This is about structures that largely fail to adhere to the traditional values of Istrian rural architecture and, what is even worse, because they are being built in the continuation of villages; they seriously compromise the vista of these villages. This has caused many Istrian villages to lose the contours they once had, and is also threatening to take away their identity.

Old Istrian houses made of stone are being transformed into villas by the addition of swimming pools, the installation of floor or wall heating and air conditioning, garden landscaping of the plots around the house, and the construction of parking lots and garages. In most cases, however, new houses are constructed that are then sold as "typical Istrian houses", although they are, in fact, but a mixture of styles in the liberal interpretation of selfproclaimed architects or architects that make designs according to what the investor wants. "Most villas on offer are typical examples of kitsch; despite high prices, certain details are repeated serially (regardless of the builder): a combination of traditional (stone) and modern construction materials, "decorative" panelling made from stone slabs, wooden floor panelling, "patches" of stone visible in plastered walls, façade bricks, stainless steel and plastic" 


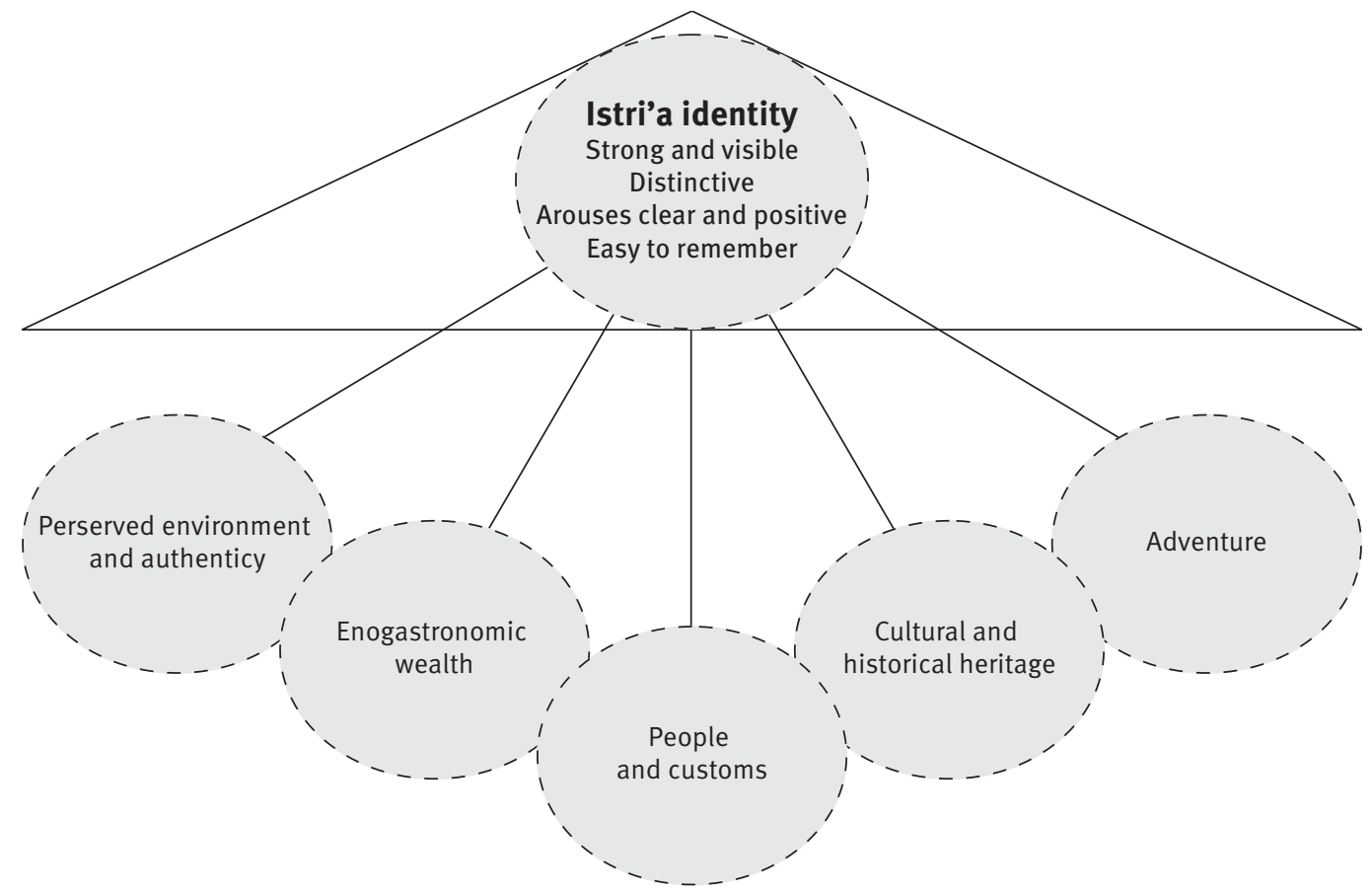

Figure 2. Umbrella branding

Source: www.futuria.hr/category/branding-drzava-i-regija/

(Matejčić, Glas Istre, IO.O3.2008). Developing and branding the entire Istrian tourism destination is based on the umbrella brand concept (Figure 2).

As its name indicates, the umbrella brand should be the primary provider of Istria's identity, covering or carrying all other key elements of the region's tourism and economic (market) identity. Because Istria is not only about tourism, this makes it necessary to fully exploit everything that comes under the umbrella. The target of this type of brand is to makes guests sensitive to authenticity and to weave into their memories images and pictures that are set in tradition. Creating an identity and image for Istria using comparative advantages (the elements under the umbrella) is based on the following:

- A preserved environment and authenticity in combination with a favourable geographical position evoking docility, romantic charm, peace, harmony, co-existence with nature, the blending of green and blue in nature;

- A profusion of eno-gastronomic delights evoking a gourmet heaven, health food, healthy living, agritourism, restaurants and konobas;

- People and customs associated with life in harmony with nature, work, integrity, openness, cordiality;

- Cultural and historical heritage associated with the region's turbulent, rich and interesting history and its cultural heritage;

- Adventure associated with ideal sites for adventure sports (specific areas should be promoted, especially via the Internet - with detailed maps and motivational material). (www.futuria.hr) 


\section{Conclusion}

The research conducted by the authors of this paper has answered the question of whether the preserved traditional architectural heritage of rural Istria is capable of enriching the tourism offering and enhancing its competitive ability and performance.

The authors have concluded that by using the elements of traditional architecture in designing settlements and their surroundings, in changing the use and organisation of private family farms, and in constructing and furnishing typical stone houses, a specific form of tourism can be developed in the rural areas of Istria that is capable of ensuring high competitive ability and greater tourist spending.

Experience up to date has provided evidence of excellent results being achieved by private family farms that have been transformed into tourism facilities in alignment with the principles of traditional architecture. These results are reflected in higher occupancy rates expressed in days and in rental prices that are several times higher than usual. This confirms the hypothesis that the preservation of traditional architectural heritage has a positive impact on enriching the tourism offering and the destination at large.

\section{References}

Conrads, U., (I997), Programi i manifesti arhitekture XX. Stoljeća, Biblioteka psefizma, (Zagreb: Nakladništvo udruženja hrvatskih arhitekata).

Cresti, C.: Le corbusier, (I969), Majstori dvadesetog stoljeća, (Zagreb Naprijed).

De Chiara, J. Crosbie J. M., (2OOI), Time-Saver Standards for Building types,( fourth edition, Mc Graw Hill).

Dobrović, N., ( I963), Savremena arhitektura, 2 pobornici, (Beograd: Prosveta).

Đikić, D., (2OOI), Ekološki rječnik, (Zagreb: Ministarstvo okoliša i prostornog uređenja $\mathrm{RH})$.

Freeman, C., Buck, O., (2003), Development of an ecological mapping methodology for urban areas in New Zealand, Landscape and Urban Planing, 63 (30).

Gazvoda, D., (20O2), Caracteristics of modern landscape arhitecture and its education, Landscape and Urban Planing, 60 (30).

Halprin, L., (I974), Gradovi, (Beograd, Građevinska knjiga).

Hehl-Lange, S., (2OOI), Structural elements of the visual landscape and their ecological functions, Landscape and Urban Planing, 54 (55).

Jencks, C., (I986), Moderni pokreti u arhitekturi, Iro (Beograd:Građevinska knjiga).

Koch, W., (I997), Építészeti stílusok, Az európai építőművészet az ókortól napjainkig, Officina Nova).

Larsen, L., Harlan, S., L., (2006), Desert dreamsccapes: Residential landscape preference and behavior, Landscape and Urban Planing, 78 (I5).

Matejčić, S.: Glas Istre, IO.O3.2008.

Mazzotti, F., J., Morgenstern, C., S., (I997), A scientific farmework for managing urban natural areas, Landscape and Urban Planing, 38 (I5).

Marasović, T., (I994), Graditeljstvo starohrvatskog doba u Dalmaciji, (Split: Književni krug).

Ružić, P., Amidžić, D., Poropat, A. (2007), Preserving Traditional Arhitectural HeritageFactor in the Tourism Valorisation of Rural Istria, HOTELlink Beograd, 7 (9-IO). 
Strižić, Z. (I997), O stanovanju arhitektonsko projektiranje, Biblioteka psefizma Zagreb, Nakladništvo udruženja hrvatskih arhitekata.

www.pannoniantourism.hu, 07.08.2008.

www.heartofistria.org, I2.08.08.

www.heartofistria.org/fileadmin/documents/news/Orbanic-Arhitektura_ambijenta.pdf, I5.08.2008.

www.futuria.hr/category/branding-drzava-i-regija/, I5.08.2008.

www.futuria.hr, 05.09.2008.

www.oglas.hr, 05.09.2008.

www.adriamosaic.com, 05.09.2008. 